\title{
The Investment and Net Interest Margin: Case Study Commercial Banks in Kosovo
}

Fidane Spahija

Lecturer, University “Haxhi Zeka”, Kosovo

fidane.spahija@unhz.eu

\begin{abstract}
In Kosovo, but in all developing countries, the foreign investment is the locomotive of the country that considered as the most important economic sectors. In general it can be concluded that most of the investment originates from developed countries and that these investments return to these places. Origin of investments in Kosovo mainly comes from countries such as Austria, Germany, Slovenia, Great Britain, Switzerland, Turkey, the Netherlands, Albania, Serbia, USA, France, Macedonia, Croatia, Cyprus, Norway, Italy, Greece etc. The banking sector in Kosovo has been very attractive to the foreign investors. A total of nine commercial banks, seven are foreign owned. Foreign investments are primarily generated as investments in shares of foreign shareholders from different countries of the world. Investments in securities have increased by the banking sector in 2014. With the change of the interest rate it has also changed net interest margin of the banking sector. Interest on loans and deposits has continued to decline. Especially interest rates on deposits in 2014 have fallen to 1. 1\%. This linked to the investment bank in securities of our government as the initiator in this area but cannot be denied to the investment of foreign governments. With the decrease of credit interest rate will be the development of sustainable economic growth and boost investment.
\end{abstract}

Keywords: Commercial banks; Investments; Net interest margin

\section{Introduction}

The foreign investments are the main segments of the economic activity of a country. The most attractive sectors for FDI in developing countries and countries in transition are the mining, minerals, metals, food production and the traditional sectors of industry, chemical industry, services and public infrastructure (especially energy and telecommunications).

The banking sector in Kosovo also has been very attractive to foreign investors. A total of nine commercial banks, seven are foreign owned. And three major banks in Kosovo that consistently generate high profits are from foreign-owned banks. Foreign investments are mainly generated as investments in shares of foreign shareholders from different countries of the world. In general it can be concluded that most of the investments originate from developed countries and that these investments return to these places. Origin of investments in Kosovo mainly comes from in Kosovo mainly come from countries such as: Austria, Germany, Slovenia, Great Britain, Switzerland, Turkey, the Netherlands, Albania, Serbia, USA, France, Macedonia, Croatia, Cyprus, Norway, Italy, Greece etc. In the financial account of the balance of payments under liabilities, the main category continues to be the category of FDI, whereas the main category are assets are the other investments (mainly deposits and commercial loans) outside Kosovo's economy. Analysis of investment in shares in commercial banks in Kosovo shows that foreign-owned banks continue to dominate with higher amounts in the financing of capital stock although their amounts were constant continuously while analysis of net interest margin that is calculated with ex-post method, as the difference in interest rates on loans and deposits that banks specify in the contract from the outset. This indicates that banks play an important role in the economic development of a country but without leaving aside their own benefits. If we would decrease the interest rate on loans will have to further develop sustainable economic growth, increased foreign investment, increase funding capital stock, increasing investment in securities but also risk greater for banks and they undertake, due to reduction of their net margin. 


\section{Literature review}

Broadly understand collaborating with investment of funds, real estate, securities (stocks, bonds, etc. ), studies and scientific research, education of personnel, etc., and the goal of all these investments is to maximize profit. So we recognize investment in real assets and financial assets. The purpose of investing is to ensure the existence of unsafe surroundings, increasing the level of efficiency and well-being now and in the future, etc. Investment needs arising from the hinterland through the competition and this dictates the need to improve the technology, the ability of personnel, increasing the range of products, market occupation in the country and abroad, etc. Investments can be defined as commitment of funds, or other material goods be expressed financially, for the realization of development goals and the investments represent an act of conscious withdrawal from the consumption of current in the name of hope for the greatest effects serial in the future (risk and profit are inseparable and are proportional to the rational investor but minimizes risk and requires adequate return). (Kadareja, 2012) During the investment should be considered serial effects that are expected from investment in the future and the uncertainty and risk that accompany the investment. Regarding investments Massa says "investment represents parts of a good safe from consumption of which waived, with the hope that we have the facility of investing" while SHARPE says "investment is sacrificing value to the current value to the future with great potential, "he Also it makes the difference between saving and investment. While savings represents waiver of consumption, investment made for output could be achieved in the future. Keeping money disengaged or spending it on consumption, is a waiver of return on investment. The desire of investors is much greater profit, but faced with the risk of investment. Foreign direct investments are one of the main economic activities Tucked country, especially in developing countries such as Kosovo. According to OECD (2007), FDI reflect the intention of securing a lasting interest in either direct or indirect economy. They work out of the territory of the country of the investor. That an investment be considered FDI subsidiary parent should invest at least $10 \%$ of the usually shares from its foreign subsidiaries. (Zoto, 2012) Investments in shares are owned by the assets of a joint stock company and have virtually no predetermined maturity date. Shares are divided into: common shares and preferred shares. (Asllanaj, 2010) The advantages are that investors in stocks, dividends benefit, the size of which is variable according to economic conditions and the progress of the corporation; Open the possibility for capital gains, i. e. They can bring extra benefits; In case of bankruptcy or liquidation of the corporation have limited liability to the creditors until the settlement of the value of investing in shares. Maximum loss is the value that shareholders invested in stocks; Lower cost of service for their possession; Maintaining high security (currently in book-entry form). Currently not verified ownership of shares in the form of materialized (with certificate), but in the form of computer records. Investor will be issued a receipt (document) that proves ownership to ownership. Book-entry system protects investors from losses, forgery, theft, etc. securities. The rate for buy and sell them, etc. Bernanke was determined by the cost of mediation as the difference between the costs paid by the borrower's gross and net returns obtained by savers. (Bernanke, 1983)

Although there is no single definition of the interest margin in the empirical literature, one that prevails is the net interest margin (ratio of net interest income to earning assets). Often times, this indicator is calculated in relation to total assets and the changes are not very significant if earning assets comprise a significant part of total assets. There are two ways of measuring the net interest margin, and ex-post ex-ante. Under the first approach, the net interest margin is calculated as the difference between interest rates on loans and deposits that banks specify in the contract from the outset. These are the rates that the public sees and that are readily comparable among them. Under the second, the indicator is calculated as the difference between the interest income and expense that the bank has realized during the period, according to data from financial statements (once attained). The difference between the two margins is related to the loans. Another treatment determinants margin is the theoretical interests. For the first time such a treatment is performed by Ho and Saunders (1981) and was named model of intermediation.

\section{Methodology}

Theoretical paper for the primary data are scientific works published in international journals and conferences and secondary data are other publications, books and articles by local and foreign authors. For the practical part of the paper records are investiture central bank reports, the financial statements of commercial banks, from data Monetary Fund International and the World Bank for Kosovo, the ministry of research reports, agencies and institutions operating in the country. Research methods are used, the method of statistical analysis, and comparative. The data presented cover the period 2011-2014. 


\section{The foreign direct investment in Kosovo}

FDI are the main segments of the economic activity of a country. Kosovo but also in the developing countries, considered as the locomotive of the country that focus on important economic sectors.

In general it can be concluded that $92 \%$ of investments originating from developed countries and $72 \%$ of them return to these places. (Riinvest, 2002). The most attractive sectors for FDI in developing countries and countries in transition are the mining, minerals, metals, food production and the traditional sectors of industry, chemical industry, services and public infrastructure (especially energy and telecommunications). Sector Banking and Insurance were among the most attractive sectors for foreign investment in postwar Kosovo. These sectors have absorbed $€ 30.6$ million, of which $19.3(63 \%)$ is the share of foreign capital which consists of 13 million $€$ of the banking sector and $€ 6.3$ million of insurance. (Riinvest, 2002). The origin of investment mainly comes from countries as indicated in table below.

\section{Table 1. Investment by countries}

(In million of Euros: State on 31 December 2014)

\begin{tabular}{|c|c|c|c|c|c|c|c|}
\hline \multirow[b]{2}{*}{ Code } & \multirow[b]{2}{*}{ Countries } & \multicolumn{3}{|c|}{ Total Imward Direct hvestment } & \multicolumn{3}{|c|}{ Total Outverd Direct hrvestment } \\
\hline & & & Equity capital & $\begin{array}{l}\text { Other capital } \\
\text { transactions }\end{array}$ & & Equity capital & $\begin{array}{l}\text { Other capital } \\
\text { transactions }\end{array}$ \\
\hline & Earopean Union & 987.0 & 755.0 & 232.0 & 74.3 & 62.4 & rig \\
\hline AT & Alstria & $\$ 9.9$ & 83.4 & 8.4 & 3.6 & 3.3 & 0.3 \\
\hline $\mathrm{BE}$ & Bebium & 2.8 & 9.5 & 3.3 & 2.7 & 2.7 & 0.0 \\
\hline$B O$ & Bubgaria & 316 & 3.8 & 278 & 0.6 & 0.6 & 0.0 \\
\hline $\mathrm{Cr}$ & Cypns & 6.7 & 2.0 & 47 & 3.7 & 3.7 & 0.0 \\
\hline FR & France & \$.4. & 8.2 & -0.8 & 3.1 & 3.1 & 0.0 \\
\hline$D E$ & Germany & 259.5 & 249.2 & 4.3 & 212 & 212 & 0.0 \\
\hline$\propto$ & Gresce & 9.5 & 8.8 & 0.7 & 19 & 10 & 0.0 \\
\hline$\pi$ & Ealy & 6.9 & 8.9 & 0.1 & 3.3 & 3.3 & 0.0 \\
\hline Ne. & Nethertands & 84.1 & 145.8 & 38.4 & 81 & 3.5 & nt6 \\
\hline$\infty$ & Romeria & 3.8 & 3.7 & 0.1 & 0.3 & 0.3 & 0.0 \\
\hline si & Sloveria & 28.7 & 87.5 & 120.2 & 75 & 7.5 & 0.0 \\
\hline SE & Swedien & $\pi 3$ & $\nabla .0$ & 0.3 & 12 & 12 & 0.0 \\
\hline \multirow[t]{2}{*}{$\infty$} & Unzed Kangdom & 38.7 & 35.2 & 35 & 6.4 & 6.4 & 0.0 \\
\hline & Other EU Countries & 312 & 27.2 & 4.0 & 3.8 & 3.8 & 0.0 \\
\hline & other Eropean Countries & 644.3 & 442.6 & 2016 & 85.5 & 84.7 & 0.7 \\
\hline AL. & Abaria & 98.5 & 60.3 & 38.2 & 32.8 & 32.2 & 0.6 \\
\hline ir & Croexia & r.s & 9.6 & 2.3 & 3.3 & 3.3 & 0.0 \\
\hline MK & Macedoria, FYR & 24.5 & 4.5 & 0.0 & 0.5 & 10.4 & 0.0 \\
\hline No & Nonway & 8.1 & $* .9$ & 12 & 0.6 & 0.6 & 0.0 \\
\hline RS & Sertia Republic of & 14.3 & 0.6 & 3.8 & 6.4 & 6.4 & 0.0 \\
\hline $\mathrm{Cr}$ & Swezzerland & ซ8.6 & 158.1 & 20.4 & 0.3 & 10.2 & 0.1 \\
\hline \multirow[t]{2}{*}{ TR } & Turkey & 2916 & 66.8 & 124.8 & 3.8 & 3.8 & 0.0 \\
\hline & Other Erropian Countries & 20 & 7.8 & 12 & 0.8 & 10.8 & 0.0 \\
\hline & other courtives & 28.5 & 04.9 & 235 & 4.8 & 14.8 & 0.0 \\
\hline us & Unted States & 69.0 & 515 & 175 & 79 & 79 & 0.0 \\
\hline \multirow[t]{2}{*}{$A E$} & Unked Arab Enirates & 37.4 & 32.8 & 4.6 & 15 & 15 & 0.0 \\
\hline & Other Countries & 22.1 & 20.6 & 15 & 5.4 & 5.4 & 0.0 \\
\hline \multirow[t]{2}{*}{$2 z$} & Not Spedified & $1,09.3$ & 936.5 & 262.8 & 0.0 & 0.0 & 0.0 \\
\hline & Orand Tota & $2,050.1$ & $2,239.2$ & 720.0 & $\pi 4.6$ & 819 & 2.6 \\
\hline
\end{tabular}

In the financial account of the balance of payments under liabilities, the main category continues to be the category of FDI, whereas the main category are assets and other investments (mainly deposits and commercial loans) outside Kosovo's economy. FDI balance was characterized by deterioration in 2014, mainly determined by the decline of FDI in the country, which was reduced to 151. 3 million euros from 280. 2 million euros as they were in 2013. (CBK, 2015) 


\section{Table 2. Financial account}

(In million of Euros)

\begin{tabular}{|c|c|c|c|c|c|c|c|c|c|c|c|c|c|c|}
\hline \multirow{2}{*}{ Bostiption } & \multirow{2}{*}{ Bidume } & \multirow{2}{*}{$\begin{array}{c}\text { hualmets } \\
\text { Evodid }\end{array}$} & \multirow{2}{*}{ 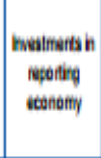 } & \multicolumn{3}{|c|}{ Orest hasamerts } & \multicolumn{3}{|c|}{ Peatlolo invalinarts } & \multicolumn{3}{|c|}{ Allse hivalineth } & \multirow{2}{*}{$\begin{array}{l}\text { Finetial } \\
\text { detentitio }\end{array}$} & \multirow{2}{*}{$\begin{array}{l}\text { hewew } \\
\text { waith }\end{array}$} \\
\hline & & & & & Actoas & 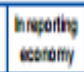 & & Adouad & 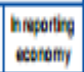 & & Adoud & 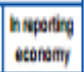 & & \\
\hline 2004 & stis & $4 \mathrm{~A}$ & DSB & 420 & - & 42.9 & 2.1 & 2.1 & - & 860 & tab & 620 & . & - 12.7 \\
\hline coss & .38 & 24. & 809 & .078 & - & tis & tis & to & - & 887 & His & 728 & . & 32 \\
\hline 2006 & 35.7 & 3725 & 256 & 2 & $4 B$ & 24 & 65A & BSA & - & 846 & 28. 7 & 370 & . & $\pi n$ \\
\hline 2007 & $\$ B$ & 5025 & 502.7 & 450 & 2f & 40.7 & 3.5 & 34.5 & - & toif & กטด & 619 & . & 2003 \\
\hline 2006 & $\sqrt{3} \mathrm{~s} / \mathrm{A}$ & 2312 & SQB & 345 & $2 M$ & 309 & tos & tot & - & .721 & tot & w. & . & 82 \\
\hline 2000 & .600 & 2038 & 3089 & פרו2 & of & $27 / 4$ & ou & tos & os & w3 & to. & Stb & . & .48 \\
\hline 200 & $27 \mathrm{SB}$ & 4038 & แ6 & $\$ 11$ & $3 / A$ & 386 & 485 & $48 B$ & - & 46.7 & 268 & 329 & . & 54 \\
\hline wil & $m s$ & 8.9 & 4612 & פ578 & 95 & 344 & 578 & 578 & - & 48 & 817 & 968 & . & 812 \\
\hline 2000 & . 10 & $38 \mathrm{~B}$ & 478 & 203 & $\Delta$ & 2.1 & $8 \%$ & 84 & - & 3149 & - Hes & 2365 & . & wh \\
\hline 2000 & . 1222 & 202 & 304 & .4002 & 300 & 2002 & 023 & tos & - & H.A. & bis & Ab.1. & . & $\$$ \\
\hline $20 \%$ & . 14.1 & W/ & 254 & .250 & 273 & ธtง & as & is & - & 226 & DAS & $\omega$ & . & StD \\
\hline
\end{tabular}

FDI in Kosovo are mostly concentrated in sectors of the economy such as real estate to 142.1 million euros from 151. 2 million euros in total FDI carried out in Kosovo in 2014, financial services with 41.9 million euro, energy by 13.4 million euro, trading 8.4 million. (CBK, 2015) The value of investments in real estate has steadily increased (4.5 percent increase in 2014) and the financial sector who noted that in previous years has decreased in 2014 increased significantly. The important component within the balance of payments is the category of Foreign Direct Investments (FDI). In 2014, the balance of FDls was euro 123. 9 million, which represents a significant decline compared to the value of euro 250.2 million in the previous year. This decline in FDls can be attributed mainly to the sale of shares of some of the foreign companies operating in Kosovo to the Kosovo residents and distribution of the super dividend of some of the foreign companies operating in Kosovo.

Chart No. 1. Structue of FDI by components, in millions of euro

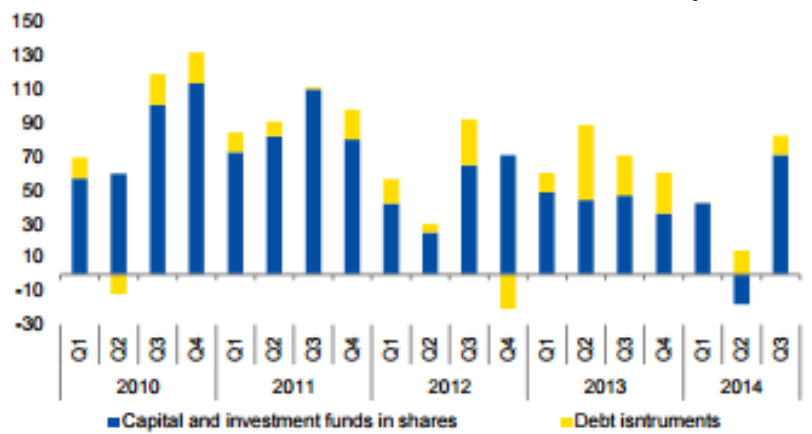

Source: CBK (2015) 


\section{In general for banking sector in Kosovo}

Reform of the banking system in Kosovo after the war began in 1999, led by the Banking and Payments Authority of Kosovo (BPK), as the forerunner of the Central Bank of Kosovo (CBK). The banking system plays a very important role in the financial system in Kosovo, whose assets account for about 90 percent of the assets of the entire financial system. Banks have become key actors in channeling funds from lenders to borrowers, source of funding for businesses, individuals and economic development in general. Therefore, it is very important that their intermediary role to ensure a higher welfare for society, possibly much lower cost.

The structure of the banking sector in Kosovo in 2014 was similar to previous periods. According to the ownership structure of the banking sector continued to be dominated by foreign-owned banks, whose assets make up 90.4 percent of total assets of the banking sector, while the remainder is managed by the local banks. (CBK, 2015) The table number 3, which indicated that commercial banks operating in Kosovo and their filial. Besides Bank for Business (No. 4 in the table) and the Economic Bank (no. 5 in the table) which are locally owned, all other banks are foreign owned.

Tabel No. 3. Commercial banks and their branches

\begin{tabular}{|l|l|l|}
\hline No. & Name of bank & Branches \\
\hline 1. & Procredit Bank & 55 \\
\hline 2. & Raiffeisen Bank Kosovo J. S. C & 52 \\
\hline 3. & NLB Prishtina & 50 \\
\hline 4. & Business Bank & 41 \\
\hline 5. & Economy Bank & 40 \\
\hline 6. & TEB & 26 \\
\hline 7. & National Commercial Bank & 24 \\
\hline 8. & Komercijalna Banka - Mitrovica & 9 \\
\hline 9. & Turkiye is bankasi - Pristina & 1 \\
\hline & Total & 298 \\
\hline
\end{tabular}

CBK (2015)

\section{Investments in shares in foreign-owned banks in Kosovo (2011-2014)}

Investments in shares are owned by the assets of a joint stock company and have virtually no predetermined maturity date. Shares are divided into: common shares and preferred shares. Advantages of investments in shares are ambitious. The following analysis shows investment in shares for the five foreign-owned banks in the four quarters of the years 2011-2014, issued by the balance sheets of commercial banks in Kosovo.

\section{Chart no. 2. Investments in shares 2011 Chart no. 3. Investments in shares 2012}




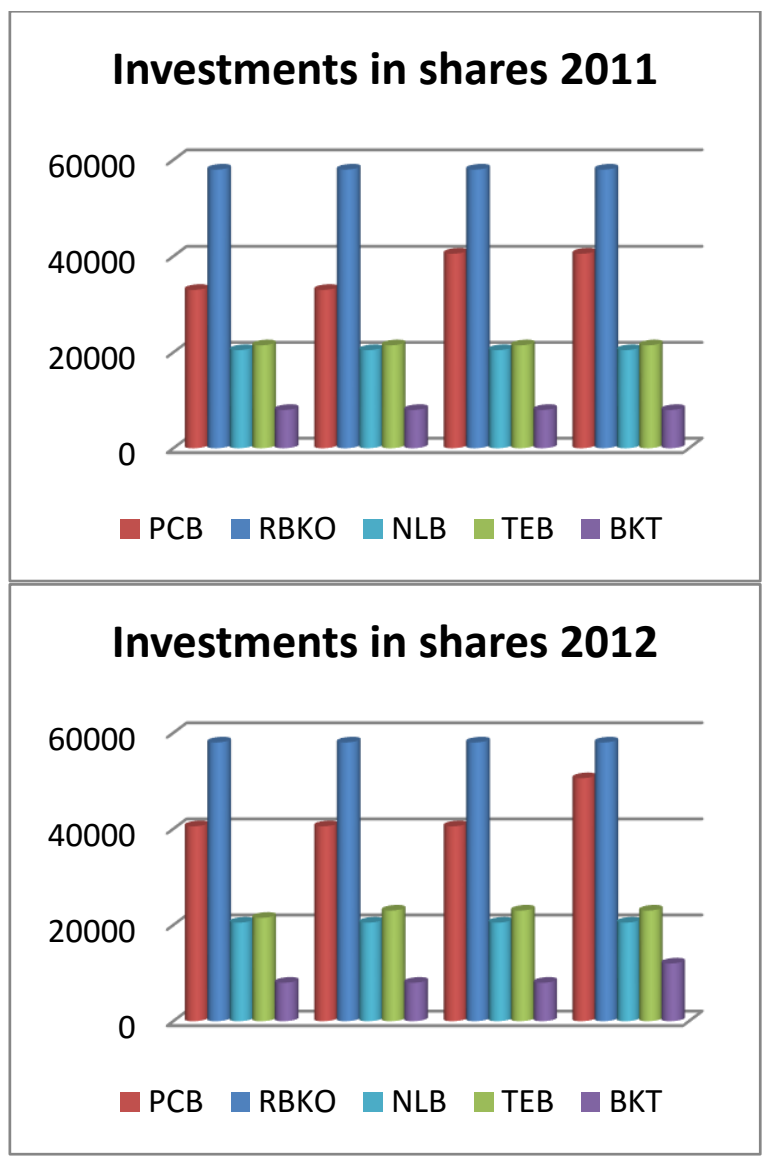

Chart no. 4. Investments in shares 2013 Chart no. 5. Investments in shares 2014

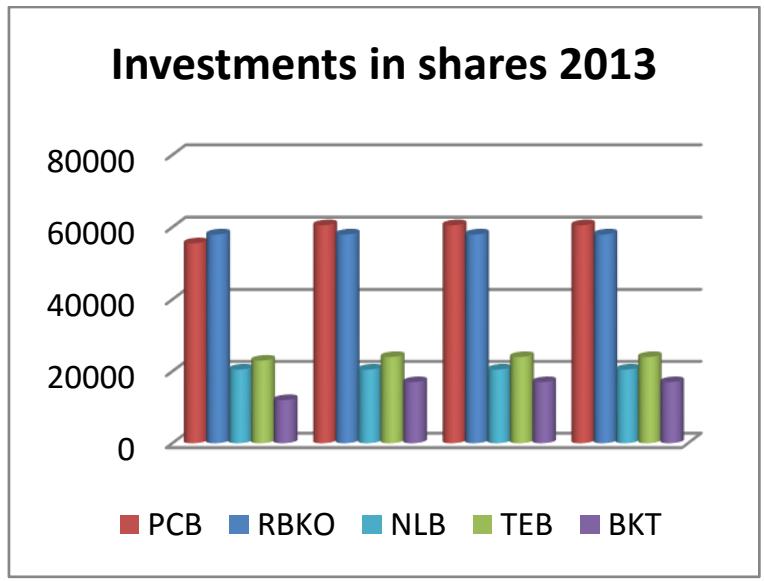




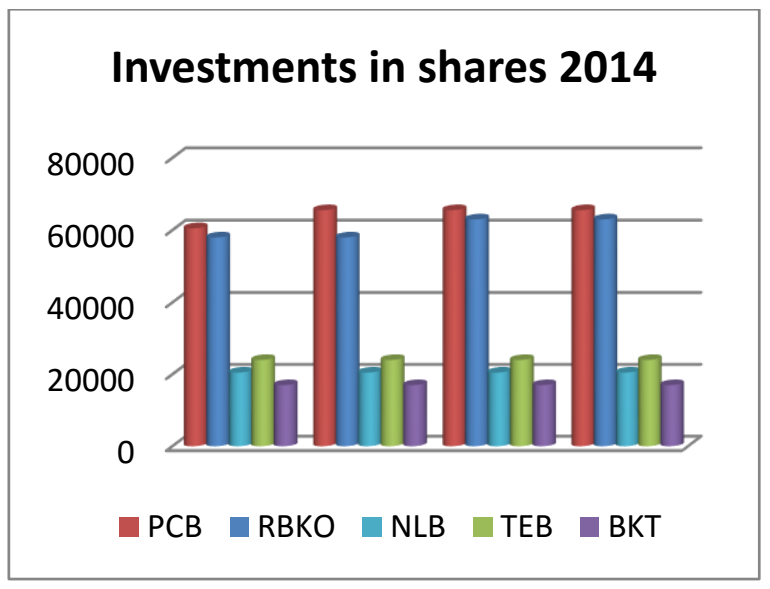

From the charts we see that two foreign banks and the largest in the country (Raiffeisen Bank and ProCredit Bank) have the largest investment shares. In 2011 and 2012 leads Raiffeisen bank and in 2013 and 2014, Procredit Bank reaches and exceeds 2550 Raiffeisen for more shares. Then the investment is participation in Turkish bank TEB shares following the NLB Prishtina, while smaller participation in National Bank has shares trading.

\section{Net interest margin on commercial banks in Kosovo}

Net interest margin is called NIM (Net Interest margin) represents the cost of mediation between interest income and interest expenses. Interest income includes amounts arising from credits that banks grant a customer and get paid every month in the form of installments, while interest expenses include amounts arising from savings as a result of the deposit to the bank by private, where the amounts exceed the amounts deposited represent interest expense that the bank must give them to customers. There are two ways of measuring the net interest margin, and ex-post exante. Under the first approach, the net interest margin is calculated as the difference between interest rates on loans and deposits that banks specify in the contract from the outset. Under the second, the indicator is calculated as the difference between the interest income and expense that the bank has realized during the period, according to data from financial statements (once attained). In the analysis it was evaluated with the net interest margin exante method for commercial banks in Kosovo in four-year period 2011-2014.

\section{Chart no. 6. Net margin interest rate in percentage}

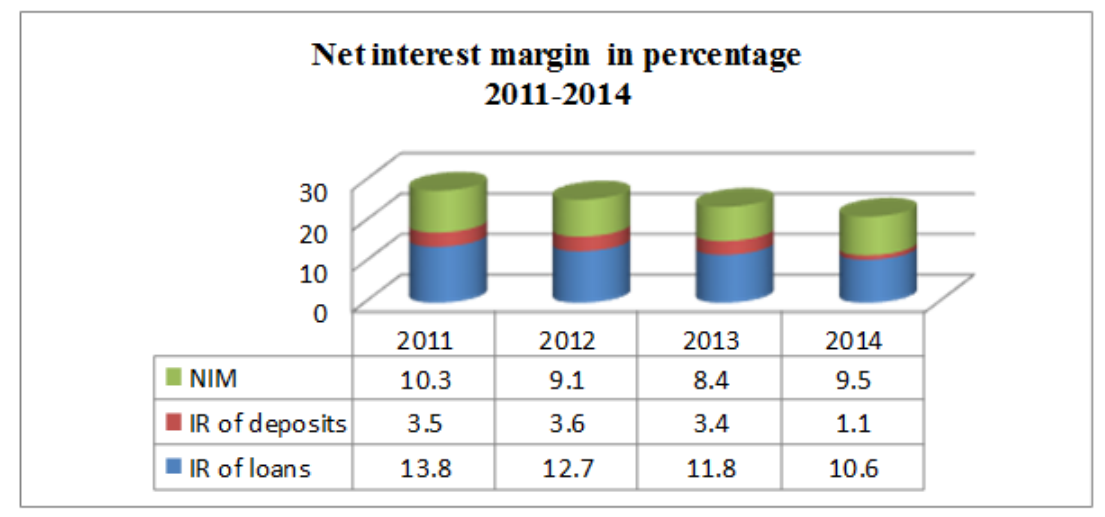


From the picture we see that effective interest rates of loans issued by the Central Bank data to Kosovo since 2011-2014 have continued to decline, from 13. 8\% in 2011 to 10. 6\% in 2014. In comparison with rates deposits of which also declined notably in 2014 with $1.1 \%$ in the interest rates in 2012 and $3.6 \%$ in the interest rates.

The difference between the interest rate on loans and deposits gives us the net interest margins of commercial banks in Kosovo.

From the chart we can see that the net interest margin was lower in 2013 by $8.4 \%$, while in 2014 rose to $9.5 \%$, which was due to the decline in deposits at $1.1 \%$. This shows that the banks have created liquidity to adequate and that there is more need for deposits.

If you give a look at the graph of investment in shares of commercial banks in Kosovo, then we can say that investing in shares have remained constant from year to year, they more have helped banks to start immediately to after opening their branches, we these last four years we noticed that most banks were generates more from retained earnings and net profit for the year is shown by margins net of interest and less deposits. Because the rate of interest for deposits has fallen in 2014. Fall of the deposit interest rate to be compared with the graph of investment in securities from commercial banks where it is noted that banks have had an increase of $8.3 \%$ in 2014.

\section{Results \& Discussions}

The investments whatever are like as firm or country, whether made directly or indirectly for the purpose of profit growth or sustainable development. From analysis to see FDI in Kosovo in the past year they have decreased, not as generous thing for our country. Investments in shares of commercial banks in Kosovo have remained constant and dominated by foreignowned banks. Investments in securities of commercial banks in Kosovo have increased in 2014.

The analysis of net margin, effective interest rates on loans have continued to decline, from $13.8 \%$ in 2011 to $10.6 \%$ in 2014. In comparison with the deposit interest rates, which also declined notably in 2014 with $1.1 \%$ in the interest rates in 2012 and 3. 6\% in the interest rates? Net interest margin was lower in 2013 by $8.4 \%$, while in 2014 rose to $9.5 \%$, which was due to the decline in deposits at $1.1 \%$. This shows that the banks have created liquidity to adequate and that there is more need for deposits. Fall of the deposit interest rate to be compared with the graph of investment in securities from commercial banks where it is noted that banks have had an increase of $8.3 \%$ in 2014.

More or less expected results have known that we are a developing country and battling every day.

Evidently interest rate interconnection with net margin, as higher is the interest rate the higher will be the net margin, and it is clear that the interest of commercial banks is to maximize profits.

\section{Conclusions}

With this paper, we came to the conclusion that what investments will have an impact on whether the sustainable development of a country. Kosovo but also in the developing countries, FDI is considered as the locomotive of the country after that focus on important economic sectors. In general it can be concluded that most of the investments originate from developed countries and that these investments return to these places. The origin of investment by state in Kosovo mainly come from countries such as: Austria, Germany, Slovenia, Great Britain, Switzerland, Turkey, the Netherlands, Albania, Serbia, USA, France, Macedonia, Croatia, Cyprus, Norway, Italy, Greece etc. The banking sector in Kosovo has been very attractive to foreign investors, immediately to the war. A total of nine commercial banks, seven are foreign owned. And three major banks in Kosovo that are constantly generating high profits are from foreign-owned banks. Foreign investments are mainly generated as investments in shares of foreign shareholders from different countries of the world. Investments in shares have been constant from year to year, but dominated by foreign-owned banks. Banks which have much larger shares of investments in Kosovo are Procredit and Raiffeisen bank. The Turkish bank TEB, NLB and BKT then comes. Net interest margin which indicates the difference in interest rates on loans and deposits continued to grow, this variable shows how interlinked and direct effect of interest rates, changing their changing the margin. Interest on loans and deposits has continued to decline. Especially interest rates on deposits in 2014 have fallen to 1. 1\%, it can also be related to banks' investment in securities of our government as the initiator in this area but cannot be denied the investment of foreign 
governments. Most of the investments and development activities by the banks is accomplished by retained earnings or net interest margins, especially from interest income on loans. With the decline of interest rates on deposits of banks have received have sufficient liquidity and their focus is on securities, rather than in public deposits. Loans interest rates continue to remain high for our country, there is no risk but also the desire for higher profits. The market is saturated with credit and has no direction to hold. So if you have a decrease in the interest rate on loans we will have on sustainable economic development, increase in foreign investments, growth capital financing in shares, and increasing investment in securities.

\section{REFERENCES}

1. Asllanaj, Rrustem. Dr. (2010). Kontabiliteti financiar.

2. Bernanke, B. (1983). Nonmonetary effects of the financial crisis in the propagation of the Great Depression. American, 73-76.

3. BQK. (2015). Raporti vjetor. 30.

4. Dhamo, Sotiraq. Dr. (2011). Kontabiliteti financiar i avansuar. 35.

5. Kadareja, Arjan. Dr. (2012). Leksione nga lenda Financat nderkombetare.

6. Kalluci, I. (2010). Percaktuesite e marzhit neto ne sistemin bankar shqiptar. Banka e Shqiperise, 12.

7. Luboteni, Gazmend. Dr. (2008). Financat e korporatave. 64.

8. Riinvest, I. (2002). INVESTIMET E JASHTME DIREKTE NË KOSOVË. Raport hulumtues, 13.

9. Zoto, O. (2012). Punim doktorature.

10. ASK (2013-2014): Statistikat e tregtisë së jashtme: http://ask. rks-gov. net/tregtia-e-jashtme/publikimet

11. Llogaritë kombëtare: http://ask. rks-gov. net/llogarite-kombetare/ll-kombetare

12. Buletini Mujor Statistikor: http://www. bqk-kos. org/?cid=1,129 Statistikat zyrtare të BQK-së, Seritë kohore: http://www. bqk-kos. org/?cid=1,124

13. CNB (2014): Global Economic Outlook

14. European Commission (2011 - 2014): Eurostat Database;

15. European Central Bank (2011-2014): Monthly Bulletin, European Central Bank, Frankfurt

16. IMF (2014): World Economic Outlook April 2014, International Monetary Fund (IMF): http://www. imf. org/external/pubs/ft/weo/2013/02/weodata/index. aspx

17. IMF (2014): World Economic Outlook July 2014, International Monetary Fund (IMF): http://www. imf. org/external/pubs/ft/weo/2014/update/01/pdf/0114. pdf

18. Bernanke, Ben. 1983. "Nonmonetary effects of the financial crisis in the propagation of the Great Depression", American Economic Review, 73, 25 7-76.

19. Berger, A. 1995. "The relationship between capital and earnings in banking". Journal of Money, Credit and Banking. Vol. 27. 
20. Brock, Philip and Helmut Franken. 2003. "Measuring the Determinants of Average and Marginal Bank Interest Rate Spreads in Chile, 1994-2001". Mimeo Central Bank of Chile.

21. C laessens. Stijn, Asli Demirgüç-Kunt and Harry Huizinga. 1997. "How Does Foreign Entry Affect the Domestic Banking Market?". World Bank, Policy Research Department.

22. C laeys, Sophie and Rudi Vander Vennet. 2004. "'Determinants of Bank Interest Margins in Central and Eastern Europe: A Comparison with the West". Ghent University Working Papers, 316.

23. Saunders. A. and L. Schumacher. 2000. "The determinants of bank interest rate margins: an international study". Journal oflnternational Money and Finance, 19.

24. Ho, Thomas S. Y and Anthony Saunders. 1981. "The determinants of bank interest margins: Theory and empirical evidence". Journal of Financial and Quantitative Analysis,Vol. XVI, Nr. 4, 1981.

25. Demirgüç-Kunt, Asli and Harry Huizinga. 1999. "Determinants of Commercial Bank Interest Margins and Profitability: Some International Evidence", The World Bank Economic Review, Vol. 13, No. 2, 379-408. 